\title{
Sociological Aspects of Sustainable Development Perspectives in Central Lika Through the Prism of Human and Social Capital
}

\author{
Anita Bušljeta Tonković \\ Ivo Pilar Social Science Institute, Gospić Regional Centre, Croatia \\ e-mail: anita.busljeta.tonkovic@pilar.hr
}

\begin{abstract}
This paper presents a sociological view of the perspectives for sustainable development in Central Lika (Croatia) through the prism of social and human capital. The modernization processes which bypassed the entire Lika region more than they changed it left the environment and rich natural resources intact. A natural environment in this condition meets the basic conditions for articulation of the concept of sustainable development. This paper is based on the "mixed" concepts of social and human capital and the sustainable development. The study focuses on the socioecological paradigm. The research data was collected by the empirical qualitative method (semi-structural interviews) during 2012 and 2013. The participants were local social actors involved in the development of Central Lika. The results facilitated insight into the existing condition, as well as the sociological conceptualization of sustainable development perspectives in Central Lika which could be achieved via: demographic recovery measures, enhancement of civil society, education of the local population, agriculture (integrated, followed by organic), sustainable use of renewable natural resources and tourism in synergy with agriculture, tradition and ecology.
\end{abstract}

Key words: Central Lika, human capital, social capital, sustainable development.

\section{Introduction}

The social and human capital of Central Lika constitutes the sociological prerequisite for further modernization, indicating the content orientation and direction for sustainable development. The developmental opportunities in Central Lika will therefore be explored in this paper. The basic assumption is that future development should not entail a classical modernization process with its unfavourable consequences (pollution, environmental degradation, uncontrolled consumption of natural resources, etc.) but rather prospects for the meaningful transformation of former shortcomings into comparative advantages. Thus, this paper provides a developmental perspective 
that emphasizes the necessity of using modern developmental strategies based on the concept of integral sustainability. The focus is placed on a sociological analysis of select local social actors, i.e., consideration of their human and social capital as the point of departure for the sustainable development of Central Lika. The main research tasks in this paper are: to investigate the quality of the human and social capital of informants in order to explore, describe and explain the sociological aspects of sustainable developmental perspectives. Generally, the study favours the theory of structuration ${ }^{1}$ and the socio-ecological paradigm. ${ }^{2}$ Four basic concepts are used in this work. The concepts of social and human capital are linked to the concept of sustainable development. The fourth theoretical concept is modernization itself in terms of the theory and process. In a conceptual-theoretical view, modernization can be defined as a general process of transition from traditional to modern society (Kalanj, 2007; Rogić, 2000). The modernization of Central Lika can be viewed as a phase in which Lika still has an opportunity to choose its path: further modernization as a threat to the environment and community cohesion, or modernization as socio-ecological unity and prosperity. This author's preference is the second path, especially since there are many prerequisites for choosing this course.

In the interest of the clarity of further considerations, it is necessary to outline some basic information about the region in which empirical research was conducted. Central Lika is a part of the traditional Lika region that is situated in Lika-Senj County (Pejnović, 2009). All of Lika-Senj County is inside Croatia's mountain zone. It is the largest county in terms of surface area, but it has the lowest population and the lowest population density per square kilometre in Croatia. The town of Gospić, the county's administrative seat, together with the municipalities of Perušić and Lovinac, are in the focus of this research. Together they constitute the Central Lika sub-region. Central Lika encompasses the southeast part of Lika and most of Velebit Nature Park. The 1,691 square kilometre area has a population of $16,390 .{ }^{3}$ This sub-region covers the $31 \%$ of the territory of Lika-Senj County. Its population density is 9.6 inhabitants per square kilometre, which is almost identical to the county's population

$\mathbf{1}$ Within the structuration theory, social reality is understood as a reciprocal process of constructing social life through individual actions that are shaped by society (Giddens, 2007). This theory integrates micro and macro sociological approaches: generating structure through uninterrupted interaction and relationships. This author's research focus is based on an understanding of the actual structures and actions of local social actors as a reciprocal process of constructing social life in Lika's local communities.

2 The socio-ecological paradigm is a way of understanding nature and society within the context of social relations. It is closely connected to social ecology as a research orientation that aims to explore the connections and relationships between the ecosphere, socio-sphere and techno-sphere. Social ecology emphasizes the necessity of social and natural diversity and sustainability while the socio-ecological paradigm advocates socio-ecological unity, the importance of social and ecological diversity and, ultimately, a socio-ecological balance (Cifrić, 2012). In general, this paper advocates the necessity of social and ecological diversity and the socio-ecological balance in the Central Lika sub-region.

3 The data presented here have been calculated using the Croatian Bureau of Statistics database of censuses published in 2001 and 2011 (see URL. 1 in the references). 
density of 9.5 inhabitants per square kilometre. In comparison, Croatia's average is 78.4 inhabitants per square kilometre. ${ }^{4}$

Accordingly, with its current population density, Lika falls into the same category as Siberia, Northern Canada or Lapland. It is necessary to highlight that Lika-Senj County is territorially the largest county in Croatia and protected in most part due to the natural attractions. ${ }^{5}$ Therefore, human overpopulation would not be favourable, but a well-planned increase in population growth is required. In other words, if the intention is to enhance the social and human capital in a particular area, positive demographic conditions are needed. Lika's low population density is due to geographical and historical factors. The region is an isolated rural area that was repeatedly burdened by wars (most recently the Second World War and Homeland War) and by a lack of modernization processes. Political and social circumstances in general, and the socialist period in particular, have also been among the factors pushing mass migration from Lika. Socialist industrialization and urbanisation have contributed to accelerated migration from rural to urban areas, while the towns in the Lika region were not planned as major industrial centres. This led to frequent emigration outside of the county. In other words, the current population density and overall population trends are an adverse consequence of multiple socio-economical and socio-cultural phenomena that occurred during the $20^{\text {th }}$ century.

Like Lika-Senj County in general, Central Lika is mostly rural. This is shown by various official parameters. The result is the same using either the criteria of the Organization for European Cooperation and Development (a maximum 150 inhabitants per square kilometre) or European Union criteria (a maximum 100 inhabitants per square kilometre), as the population density is 9.6 inhabitants per square kilometre. This rural area, like rural areas in general, consists of four components: community, agriculture, environment and technology (Cifrić, 2003). Consequently, it should be approached through sustainable development dimensions: political, socio-cultural, economic and ecological. The political dimension focuses on the political culture of establishing and achieving social goals. The socio-cultural dimension deals with human and social capital. The economic dimension considers sustainable development perspectives in relation to the use of renewable natural resources. The ecological dimension includes preservation of biodiversity, while also maintaining the local culture, traditions and traditional skills, especially those connected to agriculture.

In the context of Central Lika, desirable human and social capital which would serve the balanced use of natural resources primarily entails a mixture of traditional and modern knowledge and skills possessed by the local population. It additionally applies to mutual trust, cooperation and cohesion that are necessary to achieve overall economic development. Such development requires adaptation of the concept of

4 The author calculated these results by using data of the Croatian Bureau of Statistics web site (Census 2011) and the ARKOD web site (see URL 1 and URL 2 in the references).

5 About half of the area of Croatia's national and nature parks (58\%) is situated in Lika-Senj County. 
integrated sustainability. It also should tap into traditional knowledge and skills for a sustainable way of using available natural resources. It is particularly useful in the development of modern agriculture and tourism.

\section{Conceptual Framework}

Short-term and unsustainable goals are not in the best interest of present and future generation. Sustainable development, as a nature-sensitive and nature-friendly way forward for human society, has become a paramount principle and a source of inspiration for many people around the world (Zeman and Geiger Zeman, 2013). This idea is taken as fundamental in this research paper. The World Commission on Environment and Development (also known as the Brundtland Commission) defined sustainable development in 1987 as development which meets current needs without endangering the needs of future generations (Our Common Future, 1987). Integral sustainability can be defined as a constant, parallel and interconnected selfrenewal process for nature and society. The self-renewal process implies a balance between economic, environmental, socio-cultural and political dimensions. In other words, integral sustainability suggests current and future self-renewal activities as an uninterrupted cycle of existence and renewal (Lay, 2007). The uninterrupted cycle emphasizes the importance of preventing and disposing of the unfavourable human interference in natural processes. Social sustainability must not be separated from the sustainability of the entire natural system, for it is nestled within it. That is why integral sustainability mandates the parallel and interconnected self-renewal of nature and society. On the other hand, integral sustainability (as well as sustainable development) does not make sense if the specific natural area is not/no longer inhabited by people. In such conditions, nature renews itself without any particular difficulty. ${ }^{6}$

The postmodern critique of modernization, a new discourse which could also be called the postmodern environmental viewpoint, describes and criticizes modernization and its industrial worldview. In pre-modern times, humans were part of the ecological balance typical of preindustrial communities. At that time, humans were directly incorporated into the natural ecosystem, more or less as passive participants in natural processes (Geiger, 2009). Combined with colonization of the rest of the world, Western modernization has destroyed environmental regulation guided by the "deranged idea and practice of conquering nature, so typical of Western civilization" (Županov, 2002:105). From that moment, nature has become an object of uncompromised exploitation. The consequences of such actions can be seen in the devastation of the natural environment. The purpose of this paper is to point out that Central Lika does not have to reach the level of pollution and devastation typical

\footnotetext{
$\mathbf{6}$ The concepts of sustainable development and integral sustainability are contextualized in a manner that emphasizes that the socio-ecological system will no longer exist (in current form) if there is no local, especially rural, community that preserves a specific area. In other words, the local community (social system) will become extinct. As it is the case in today's Lika (an area without any industrial pollution), the coexistence of humans and nature is too valuable and should be preserved.
} 
of highly industrialized zones in the developed world. Contributing to the avoidance of such consequences of modernization and industrialization, the developmental perspectives proposed here are substantial and tenable for both nature and local communities. Keeping this in mind, it is necessary to incorporate the contemporary technological achievements which do not negatively impact the environment in both rural and urban areas. It means using the advantages contemporary Western society accomplished during its modernization process. Although the socialist industrialization in this area was present until the recent Homeland War (1991 - 1995), the omission of such industrialization would accomplish the present-day efforts for sustainable development.

In order to achieve favourable results, the local community has to possess a certain level of human and social capital. Human capital is simply defined as "the knowledge, competence, skills and characteristics embodied in individuals which enable them to generate personal, social and economic well-being" (Leburić, Afrić and Šuljug-Vučica, 2009:59-60). Such capital is unique for it cannot be separated from individuals (Becker, 1964). It is indivisible from individuals; it grows through use and experience, formal and informal learning, but also diminishes if not used. Thus, human capital is not homogeneous or a static sum of skills and competences which have been acquired once and for all. The acquired capital has to be constantly used and expanded by evolving knowledge. Learning allows us to do new things. It expands our ability of creation and enables us to become a part of a generative life process that implies the sustainability of the local community and society in which we live. The knowledge and skill of select social actors in Lika constitute the human capital indicators taken into consideration for the purposes of this research. Such knowledge and skills were taken as one of the sampling criteria.

The majority of definitions of social capital have common ground in the idea that human relations are important. The main difference regarding the concept is that political science emphasizes a merger of subjective social norms (trust and reciprocity) and objective features of society (social networks). On the other hand, sociologists emphasize the social network dimension. They are more focused on interpersonal relations, i.e., involvement in different social networks (Šalaj, 2007). A combination of these two scientific views is used together in this study, with emphasis on the concept of social capital introduced by Robert Putnam. He defines social capital as the "features of social life - networks, norms and trust - that enable participants to interact more effectively to pursue shared objectives" (Putnam, 1995; Newton, 1999). Therefore, the emphasis is on trust, norms and networks, i.e., how they relate to social efficiency and prosperity as well as economic development.

Social capital is seen as one of the key components of the economic and sustainable development (Putnam, 1995; Tomanović, 2006.; Štulhofer, 2004). According to Putnam, social relations contribute to cooperation and coordination in society. The importance of close relations and face-to-face communication makes the local community an ideal generator of social capital. It is quite the same with all the other forms of associations with the potential to interconnect society (Putnam, 1995; Ignjatović and Tomanović, 2011; Johansson, Leonard and Noonan, 2012). Social 
networking, relationships, trust and social cohesion are vital to the creation of social capital. ${ }^{7}$ Social capital can be viewed as a network of sound relationships that leads to personal satisfaction by providing a meaningful life. Numerous resources available to individuals through their personal and business networks can be considered another way of generating social capital. Those resources include information, ideas, instructions, business opportunities, financial capital, emotional support, goodwill, trust and cooperation. Without well-made and well managed social networks, these resources remain inaccessible (Baker, 2003).

The social capital criteria for sampling the local actors in this study were the level of trust (particularly in small communities/villages) and social networks (especially civil society networks). The norms of reciprocity were closely associated with trust. It is important to say that even Gospić, as the seat of Lika-Senj County, is a small town (up to 10,000 inhabitants), so some level of the norms of reciprocity and trust is mostly created spontaneously. This could be a good point of departure for the further reconstruction of social capital.

At the end of this conceptual section, a question connected to the title of this paper should be answered. Why are the sociological aspects of sustainable development perspectives in the focus? Why perspectives and not a concrete sustainable development plan for Central Lika? The answer is that sociologists cannot create the sustainability plans of a certain area in all its dimensions without consulting other experts (i.e. demographers, geographers, economists, engineers, agronomists and historians). The paper is a sociological overview which provides a substantial development concept pertaining to the current state and possibilities of articulating the sociological aspects of Central Lika.

\section{Methods and Findings}

The background of the paper implied an analysis of the theoretical literature and available research so as to create an empirical study. The author used a prospective method which, in this case (from the sociological standpoint), endeavours to clarify the perspectives for sustainable development in Central Lika. The nature of empirical research necessitated the use of qualitative methods of interviewing, primarily semi-structured interview both in the first and second round of fieldwork. The interviews were conducted with some of the developmental social actors in Central Lika. The respondents were selected using structural criteria. They were considered active participants of social interactions, capable of making decisions that could, if necessary, confront established action patterns (Emirbayer and Mische, 1998). Additionally, they were selected by using sustainable dimensions criteria - political, socio-cultural, economic and ecological sustainability. The author extended the sam-

7 It is also important to point out that social capital can be constructed in negatively. Negative social capital is known as amoral familism (Banfield, 1958). Its main characteristics are a lack of trust and particular (personal/individual or familial) benefits, without the wider social networking and social cohesion. 
ple by using the snowball technique (Milas, 2005). At first, there were a few social actors chosen by sustainable criteria. They directed the author to other potential social actors. The author gathered information about these suggested social actors to decide on their participation in the study.

The qualitative interview method, the semi-structured interview, has been used to gather, analyse and interpret data that represent the basic characteristics of Central Lika's development. The first phase of research served as an opportunity to become acquainted with the selected social actors that represent a portion of Central Lika's total human capital (knowledge and skills). ${ }^{8}$ This resulted in a descriptive study. A semi-structured interview was also used in the second phase of the research, with more emphasis on the dimensions of sustainable development and social capital. The author was very much aware that this qualitative interview method did not comprise the total amount of social and human capital in Central Lika. This undercapacity could be further explained by the absence of fieldwork advantages (technical, financial, organisation, etc.), as the author conducted the research unaided. Therefore, this research might be understood as the background for further investigations, especially if one takes into account that the paper presents a pioneering study on social and human capital as elements of sustainable development in Lika. Despite all of the deficiencies, the data, along with other information gathered during fieldwork, offer a particular sociological overview of Central Lika's sustainable development perspectives through the prism of human and social capital.

Table 1

Details on participants - group and sub-group characteristics

\begin{tabular}{|c|c|}
\hline $\begin{array}{c}\text { First group: public sector and media } \\
\text { employees }\end{array}$ & Second group: self-employed \\
\hline $\begin{aligned} & \text { First sub-group: } \\
&$\[ \quad \text { representatives of national, regional } \]$ \\
& \quad \text { and local authorities } \\
& \text { - } \quad \text { representatives of local media } \\
& \text { - } \text { educators } \\
&\end{aligned}$ & 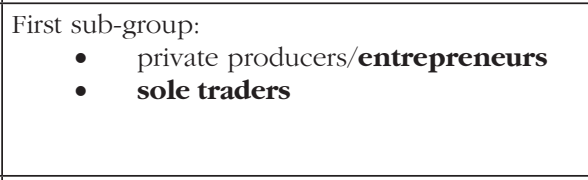 \\
\hline \multirow[t]{2}{*}{$\begin{array}{l}\text { Second sub-group: } \\
\qquad \quad \text { members of environmental } \\
\text { protection agencies }\end{array}$} & $\begin{array}{l}\text { Second sub-group: } \\
\bullet \quad \text { family farm owners (farmers) }\end{array}$ \\
\hline & 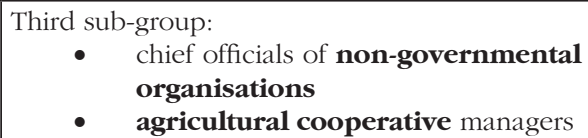 \\
\hline
\end{tabular}

8 In general, human capital consists of the entirety of human knowledge, skills and health. This research did not encompass all of Central Lika's human capital. It included some of the important social actors in order to explain the current situation and to suggest the developmental solutions. It is important to emphasize that the human and social capital of the selected social actors was not measured directly, but indirectly by using their opinions, conclusions and attitudes about relevant topics. This shortcoming was reduced by using the other methodological means, especially informal conversations and overall researcher participation in the everyday life of local communities. 
The social actors that participated in this study were divided into two groups. The first group consisted of public sector and media employees, while the second one consisted of self-employed individuals. These two groups were further divided into sub-groups in order to highlight the importance of their participation in this study. The first group of social actors was sub-divided into the following sub-groups: 1. representatives of national, regional and local authorities, representatives of local media and educators 9 ; 2. employees of environmental protection agencies. The second group consisting of self-employed individuals was divided into the three subgroups: 1 . private producers/entrepreneurs and sole traders; 2 . family farm owners; 3. chief officials of non-governmental organizations and agricultural cooperative managers. Representatives of NGOs were encompassed in the sampling to underscore the importance of enhancing civil society, which is directly related to building the social capital. The managers of agricultural cooperatives were included to stress the need for an organized market and local product placement.

The same social actors participated in the second phase of the interview. Only two persons withdrew. Hence, there were 29 interviewees in the second phase of research. It is also noteworthy that the first phase (preliminary research) was conducted during April, May and June 2012, while the second phase was conducted during June 2013. Overall, 60 interviews were conducted. See more on the sociodemographic characteristics of participants (gender, age, education level and occupation) in Tables 2, 3 and 4 .

Table 2

Demographics of sampling - age and gender

\begin{tabular}{|c|c|c|c|c|c|}
\hline $\begin{array}{c}\text { Gender and } \\
\text { age }\end{array}$ & $\mathbf{1 8 - 3 1}$ & $\mathbf{3 1 - 4 5}$ & $\mathbf{4 6 - 6 0}$ & $\mathbf{6 1}$ and older & Total \\
\hline Female & 1 & 6 & 4 & 2 & 13 \\
\hline Male & 2 & 7 & 7 & 2 & 18 \\
\hline Total & 3 & 13 & 11 & 4 & $31^{1}$ \\
\hline
\end{tabular}

Table 3

Demographics of sampling - education and gender

\begin{tabular}{|c|c|c|c|c|c|}
\hline $\begin{array}{c}\text { Education } \\
\text { level and } \\
\text { gender }\end{array}$ & $\begin{array}{c}\text { Primary } \\
\text { school }\end{array}$ & $\begin{array}{c}\text { Secondary } \\
\text { school }\end{array}$ & $\begin{array}{c}\text { College/ } \\
\text { Master's } \\
\text { degree }\end{array}$ & Doctorate & Total \\
\hline Female & 1 & 5 & 5 & 2 & 13 \\
\hline Male & 0 & 5 & 12 & 1 & 18 \\
\hline Total & 1 & 10 & 17 & 3 & 31 \\
\hline
\end{tabular}

9 The political actors in influential (although not leading) hierarchical positions at the national, regional and local authorities were chosen for several reasons. First, all of them are highlyeducated and young. So it could be said that their opinions and visions of development and progress are more significant. Second, all of them are planning to stay in politics and become candidates for jobs they already do (subsequent term) or for a leading role in local politics. 
Table 4

Demographics of sampling - occupation and gender

\begin{tabular}{|c|c|c|c|c|c|c|c|c|c|}
\hline $\begin{array}{l}\text { Occupation } \\
\text { and gender }\end{array}$ & 㐫 & 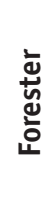 & 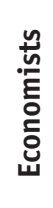 & 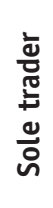 & 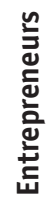 & 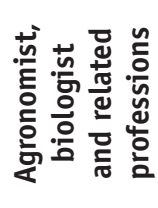 & 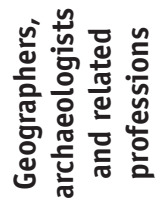 & 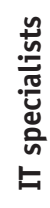 & 㟐 \\
\hline Female & 3 & - & 4 & 1 & 1 & 2 & 2 & - & 13 \\
\hline Male & 4 & 2 & 2 & 4 & 2 & 2 & - & 2 & 18 \\
\hline Total & 7 & 2 & 6 & 5 & 3 & 4 & 2 & 2 & 31 \\
\hline
\end{tabular}

The data analysis commenced after all the interviews had been conducted and transcribed. It suggests a certain analytical strategy. The one applied here consists of five stages: 1 . the establishment of analytical categories in response to field notes; 2. the consolidation of analytical categories in an analytical guide; 3. the coding of interviews according to analytical categories; 4 . the production of a case overview based on the coding; 5 . the selection of individual cases for in-depth analysis (Schmidt, 2004). Due to the small number of interviews conducted, the author used this simple type of analysis for data processing. ${ }^{10}$ The first phase started with a detailed reading of each transcribed interview in order to isolate the important segments of the text and to create analytical categories. The main objective was to note as many aspects, concepts, problems, solutions and ideas as possible. Those notes were further summarized according to their similarities. These similarities were shaped as footnotes in the margins of the transcripts. Collected analytical categories, the so-called analytical codes, were shaped and reduced. This process led the author to create an analytical guide. This was the point when analytical codes were transformed into interpretative form and further into comprehensive codes. It implies that only a part of data in analytical categories was selected. It also entailed the end of the coding process. The fifth analytical phase referenced the individual cases selected for further analysis. This analysis was made to emphasize some of the social actor's opinions and attitudes about the main topic or their own situation regarding the research subject.

The results facilitated the insight into existing conditions. Further, they paved the way for a sociological conceptualization of sustainable development perspectives in Central Lika. The initial thesis is that such perspectives are based on the enhancement of human and social capital. In other words, bolstering knowledge and skills in local communities (human capital) together with trust, norms of reciprocity and social networks (social capital) could lead to a balance between political, sociocultural, economic and ecological development. Only relevant conclusions reached during analysis are presented in the paper due to the impossibility of presenting all of the results.

$\mathbf{1 0}$ The transcribed interviews are held in author's personal archives. 
Table 5

Summarized interpretation of research results

\begin{tabular}{|c|c|c|}
\hline $\begin{array}{c}\text { CENTRAL LIKA'S DEVELOPMENTAL PROBLEMS } \\
\text { - GENERAL LEVEL }\end{array}$ & \multicolumn{2}{|c|}{$\begin{array}{c}\text { POSSIBLE SOLUTIONS TO DEVELOPMENTAL } \\
\text { PROBLEMS IN CENTRAL LIKA - GENERAL } \\
\text { LEVEL }\end{array}$} \\
\hline $\begin{array}{c}\text { Population deficit - negative demographic } \\
\text { trends }\end{array}$ & \multicolumn{2}{|c|}{$\begin{array}{l}\text { Return and employment of young people - } \\
\text { return to Lika after higher education outside Lika- } \\
\text { Senj County }\end{array}$} \\
\hline $\begin{array}{l}\text { Lack of qualified professionals and } \\
\text { incompetent management }\end{array}$ & \multicolumn{2}{|c|}{$\begin{array}{l}\text { Investing in higher education by local } \\
\text { population and recruitment of outside experts; } \\
\text { taking into consideration their expert advice }\end{array}$} \\
\hline $\begin{array}{c}\text { Underdeveloped market - illegal transactions } \\
\text { for products and retailer monopolies } \\
\text { Lack of tourist infrastructure }\end{array}$ & \multicolumn{2}{|c|}{$\begin{array}{c}\text { Market development; taking into consideration } \\
\text { cooperation with Plitvice Lakes National Park- } \\
\text { potential of a million tourists }\end{array}$} \\
\hline $\begin{array}{l}\text { Atomization of agriculture plots regarding size } \\
\text { and complicated property rights issues }\end{array}$ & \multicolumn{2}{|c|}{ New regulations (at national level) } \\
\hline $\begin{array}{c}\text { Mentality of Lika's inhabitants: } \\
\text { - } \quad \text { traditional and patriarchal heritage } \\
\text { political left or right (without any } \\
\text { concrete alternative) } \\
\text { - } \quad \text { satisfying the needs of the particular } \\
\text { interest groups }\end{array}$ & \multicolumn{2}{|c|}{$\begin{array}{l}\text { Civil society enhancement - human rights } \\
\text { associations, health promotion organisations, } \\
\text { scientific organisations, economic development } \\
\text { associations } \\
\text { Improving the democratization processes - } \\
\text { e.g. transparency in all levels of decision making }\end{array}$} \\
\hline $\begin{array}{c}\text { consequences of the Homeland War - } \\
\text { especially mined (agricultural) land }\end{array}$ & \multicolumn{2}{|c|}{$\begin{array}{l}\text { Completion of de-mining process throughout } \\
\text { Lika }\end{array}$} \\
\hline $\begin{array}{c}\text { Low possibility of access to the required } \\
\text { information (e.g. on latest agricultural } \\
\text { innovations) and computer technology for farmers } \\
\text { in rural areas }\end{array}$ & \multicolumn{2}{|c|}{$\begin{array}{l}\text { Information tables, professional services and } \\
\text { offices in rural areas, experts available on an } \\
\text { everyday basis, brochures, niers - complete } \\
\text { information access and computer courses }\end{array}$} \\
\hline $\begin{array}{l}\text { CENTRAL LIKA SUSTAINABLE DEVELOPMENT } \\
\text { PERSPECTIVES }\end{array}$ & NATURAL RESOURCES & $\begin{array}{l}\text { GENERAL } \\
\text { DEVELOPMENT } \\
\text { INTERESTS } \\
\end{array}$ \\
\hline $\begin{array}{c}\text { Agriculture (integral while later ecological) } \\
\text { - family farms with mixed source of } \\
\text { financing } \\
-\quad \text { domestic products finalization process } \\
\text { (e.g. organic food) }\end{array}$ & $\begin{array}{l}\text { Secure natural } \\
\text { environment - } \\
\text { water, soil, air, high } \\
\text { biodiversity- possibility } \\
\text { for organic farming }\end{array}$ & $\begin{array}{l}\text { Improved organic } \\
\text { agriculture: protection } \\
\text { and branding of } \\
\text { domestic products }\end{array}$ \\
\hline $\begin{array}{c}\text { Tourism in synergy with agriculture, (preserved) } \\
\text { traditions and ecology }\end{array}$ & $\begin{array}{l}\text { Protected areas - } \\
\text { pristine nature in } \\
\text { national and nature } \\
\text { parks } \\
\text { Temperate zone climatic } \\
\text { conditions - continental } \\
\text { and Mediterranean } \\
\text { climate zone -attractive } \\
\text { landscapes } \\
\end{array}$ & $\begin{array}{c}\text { Specificity of Lika } \\
\text { (geographical, historical } \\
\text { and cultural) should be } \\
\text { base in overall social } \\
\text { development of the } \\
\text { region }\end{array}$ \\
\hline $\begin{array}{c}\text { Sustainable use of renewable natural resources: } \\
\text { - } \quad \text { forests as renewable resources - } \\
\text { sustainable lumber industry: product } \\
\text { finalization process and biomass usage } \\
\text { - } \\
\text { soil without chemical contamination - } \\
\text { ideal for organic agriculture } \\
\text { - } \quad \text { water - underground waterways: water } \\
\text { bottling plant } \\
\text { - } \quad \text { sun and wind: renewable sources for } \\
\text { producing electricity }\end{array}$ & $\begin{array}{l}\text { Biodiversity as } \\
\text { possibility for achieving } \\
\text { sustainability rather than } \\
\text { exploitation }\end{array}$ & $\begin{array}{l}\text { Natural resource } \\
\text { protection and } \\
\text { sustainable usage with } \\
\text { mission to improve } \\
\text { life quality of local } \\
\text { communities }\end{array}$ \\
\hline $\begin{array}{l}\text { Education of local population (on sustainability, } \\
\text { ecology, agriculture, IT, etc.) }\end{array}$ & $\begin{array}{l}\text { Possibilities for } \\
\text { practical learning } \\
\text { on sustainability and } \\
\text { sustainable leadership }\end{array}$ & $\begin{array}{l}\text { Social cohesion } \\
\text { enhancement and } \\
\text { reducing social } \\
\text { stratification/inequality } \\
\text { among local population }\end{array}$ \\
\hline
\end{tabular}


As shown in Table 5, which presents a summarized interpretation of the research results, there are general levels developmental problems in Central Lika and possible solutions thereto. The main problems for further development are the low population, a lack of qualified professionals coupled with incompetent management, underdeveloped markets and retail monopolies together with illegal transactions for (agricultural) products. Finally, there is the excessive atomization of agriculture land together with complicated rights issues as one of the main problems. This is the first group of the problems recognized by the selected social actors. These problems are connected to the socio-economic situation. The second group of the problems is more connected to socio-cultural context. The traditional and patriarchal heritage is still strong, especially with polarization between the political left and right, as well as the practice of satisfying the needs of particular interest groups. There are also the consequences of the Homeland War, which can be recognized in poor interpersonal (ethnic) relations and particularly in poor agricultural conditions in some areas (i.e., land-mines). Limited possibilities for access to the necessary information, especially for people who live in villages - together with the need for information on the latest innovations in agriculture - are also a principal developmental problem. However, the research results provide answers to the main problems. The return and employment of young people, especially their return to Lika after higher education outside of Lika-Senj County, is a start to a solution to the low population problem. Investing in higher education by the local population and recruitment of outside experts - while offering them certain improved living conditions - are possible solutions to the second problem, i.e., the lack of qualified professionals. Regarding the atomization of agricultural plots, a new regulation at the national, regional and local level is necessary, especially due to the Croatia's EU membership. Strengthening civil society and further democratization are processes connected to the adaptation of European values, so they are unavoidable. The consequences of the Homeland War will be present for many years, but the completion of the process of clearing land-mines is a first step to higher-quality and safer living conditions in Lika's rural zones. Access to information (especially by using the telecommunication and internet infrastructure) is an inescapable condition for living in the $21^{\text {st }}$ century. As participants suggest, the first step in achieving this aim is to ensure the information tables, different services and professional offices in rural areas, experts available in on an everyday basis, brochures, fliers and computer courses. This list is additionally improved by emphasizing the need for free WiFi and HotSpots.

Development of the local market, taking into consideration cooperation with Plitvice Lakes National Park, is a vital matter. All of those interviewed highlighted the million tourists (who visit Plitvice Lakes in a single year!) in the potential for developing agriculture, handicrafts and other services. This is an important fact, especially considering the population of Lika-Senj County $(50,927)$. In this regard, a million tourists constitute a potential that could open enormous opportunities in the general improvement of local living standards.

The second part of the summarized interpretation of research results is divided into three variables. The first pertains to Central Lika's sustainable development perspectives, in which agriculture takes first place. It should be enhanced through the 
development of family farms (with mixed financing sources) and final processing of domestic products. The second perspective is tourism, but only in synergy with agriculture, tradition and ecology. The third perspective is sustainable use of renewable natural resources (forest, soil, water, sun and wind). It should be in synergy with the aforementioned two. The last perspective is education of the local population. It constitutes the basis for realization of the other three perspectives.

The natural resources of Central Lika, as a second variable, are considered within five developmental perspectives that could be presented as a secure natural environment, protected areas, temperate zone climatic conditions, biodiversity and learning for sustainability. The general developmental interests for Central Lika could thus be enumerated. They are located in: a) organic farming - protection and branding of domestic products; b) specificity of Lika - geographical, historical and cultural - that should be embedded in the region's overall social development; c) natural resource protection and sustainable use with the mission of improving the quality of life quality in local communities; d) enhancement of social cohesion and reduction of social stratification/inequality among local residents.

The results of the first phase of research point to the conclusion that the participants are aware of most of the problems, as well as the perspectives for sustainable development in Central Lika. The social actors point out problems such as the demographic deficit, the problematic organization of the local market, the lack of tourism infrastructure, neglect of agriculture and the shortage of qualified workers. On the other hand, they are also aware that modern development in Central Lika has to entail integral sustainability, since it would be based on sustainable use of renewable and non-renewable natural resources. The selected local actors confirmed the ancillary thesis that the integral sustainability concept serves as a guideline at the general and fundamental levels. They concluded that the planning, articulation and later implementation of sustainable development in local communities are processes that demand cooperation between local social actors and experts from many fields. Their answers and comments show that there is a critical mass of educated and skilled people with ideas and visions for Lika's sustainable development. The main problem they pointed out was their inability to bring to fruition certain important business ideas and objectives. They perceive the lack of social and technological infrastructure, as well as complicated bureaucratic procedures, as the primary cause of this inability.

Table 6

Sustainability levels according to the main conceptual dimensions

\begin{tabular}{|c|c|}
\hline Lower levels of sustainability & Higher levels of sustainability \\
\hline $\begin{array}{l}\text { Economic dimension (sustainable development) } \\
\text { Political dimension (sustainable development) } \\
\text { Social networks dimension (social capital) } \\
\text { Lack of expertise/knowledge dimension (human } \\
\quad \text { capital) } \\
\text { + negative demographic trend }\end{array}$ & $\begin{array}{c}\text { Environmental dimension (sustainable } \\
\text { development) } \\
\text { Socio-cultural dimension (sustainable } \\
\text { development) } \\
\text { Trust (social capital) } \\
\text { Knowledge and skills of social actors (human } \\
\text { capital) }\end{array}$ \\
\hline
\end{tabular}


The results of the second phase of research clarified the current state of sustainable development dimensions under consideration (environmental, economic, sociocultural and political; Lay, 2007). The elements of social capital in this study were adapted from Robert Putnam, including social networks, norms of reciprocity and trust (Putnam, 1993). The human capital concept and its dimensions of knowledge and skills were part of both phases of research, since the social actors were chosen according to their knowledge and skills.

Based on the processed and interpreted data from the second phase, the following conclusions have been reached. The perspectives for sustainable development in Central Lika in the environmental dimension exhibit high potential, especially considering the clean air, soil and water, forests and arable land. The only significant problem that threatens the environmental dimension is the absence of an adequate disposal infrastructure for waste and wastewater. However, a mitigating circumstance is the low population and the previously mentioned absence of industrial facilities. The economic dimension of sustainability shows poor results. The local marketplace and food production are not at satisfactory levels. Food is produced for personal needs in small and negligible quantities. There is no permanent and organized market place where it would be possible to buy locally-grown produce and meat. Also, there are no family farms with certified organic products or any form of registered rural tourism. The tourism industry is in its initial stages; it is organizationally underdeveloped. Finally, unemployment could become a bigger problem if the restructuring of local governmental institutions and state-owned companies proceeds.

It seems that the socio-cultural dimension of sustainability (especially interpersonal relationships and cooperation) still have some importance in the existence of local communities in Central Lika. The reason is the traditional way of life, with its positive aspects of mutual aid, cooperation and close interpersonal relationships. However, such a social life is affected by the aging population, and it is slowly disappearing. The demographic data clearly shows the aging trend: the average age in Lika-Senj County according to the 2011 Census is 45.3 years. Educational resources present a problem as well. The participants in both phases of the research stressed the lack of qualified professionals and also a sort of distrust in the opinions and solutions proposed by such professionals when they try to help in solve certain socio-economic problems.

A majority of the participants have expressed a regional and sub-regional identity: a sense of belonging to the Lika region, which could positively influence the sustainability of the socio-cultural dimension and contribute to preservation of "the local" in globalization processes. The results in the political dimension reveal that the current type of political culture does not contribute to a balance between the political and other dimensions of sustainability. In other words, the political culture in Central Lika is not particularly oriented towards learning for sustainability and sustainable leadership.

The social capital in the trust dimension seems relatively sustainable, although the interviewees recognize it as inherent to the older generations, which actually main- 
tain the level of trust and reciprocity norms. The social network dimension maintains its lower level, especially when the activities of non-governmental organizations are considered: most of them are interested in sports, hunting and fishing. However, social capital has prospects due to the traditionally strong interpersonal relationships (friends, neighbours, etc.). This should be taken as a mitigating circumstance that should be exploited to the benefit of the positive aspects of social capital.

The second phase results indicate that integral sustainability could be achieved by striking a balance between the four dimensions if the following criteria could be fulfilled:

1. development of the local market, supplying it with agricultural and other local products;

2. improvement of democratization on the local political scene;

3. identification of civic associations (NGOs) as vital participants in local development;

4. investment in deficitary professions;

5. appreciation of professional/expert opinion.

\section{Conclusion}

Analysing the sociological criteria for sustainable development in Central Lika, the general conclusion is that this rural area, a sub-regional part of Lika, has certain sustainability preconditions. The first one is its preserved environment, which is closely tied to organic farming. Moreover, there are possibilities for sustainable exploitation of natural resources, especially alternative energy production. The economic sustainability dimension also has possibilities in the development of sustainable rural tourism, as well as other alternative tourism activities. Sustainability in the socio-cultural dimension is reflected in interpersonal relationships, mutual assistance and cooperation, and in feelings of regional identity. Regardless of the underdevelopment of non-governmental organisations, the existence of trust and reciprocity norms is the basis for strengthening civil society and positive forms of social capital. Integral sustainability, i.e. a balance between these dimensions of sustainable development, can be achieved primarily by solving common problems like negative demographic trends, economic problems, lack of educational capacity, poor (political) leadership and management, etc., which do not comply with integral sustainably at the moment.

This paper has connected the concept of sustainable development with the concepts of human and social capital, emphasizing that the sustainability of a certain community or society as a whole cannot be discussed without considering the development of human and social capital. In other words, sustainable development cannot be nor should it be planned or preformed without consideration for the needs, ideas and visions of the local community itself. The author made an effort to present some prospects and proposals for local development together with problems that local actors consider essential. A basic task was to emphasize that the local population has its own developmental visions that take integral sustainability into consideration. 
Such visions represent a serious task for all relevant authorities and developmental actors at the national, regional and local levels.

As stated briefly above, this paper highlights the perspectives for sustainable development in Central Lika in connection with the natural resources and appropriate level of human potential (human and social capital). Hence, the perspectives for sustainable development in Central Lika, based on the research results, can be found in:

1. demographic recovery measures

2. enhancement of civil society

3. education of the local population (on sustainability, ecology and agriculture)

4. agriculture (integrated, later organic)

5. sustainable use of renewable natural resources

6. tourism in synergy with agriculture, (preserved) tradition and ecology

A discussion on the perspectives for sustainable development in Central Lika has not resulted exclusively in the representation of such perspectives. In an attempt to articulate them, this paper underlines some of the causes shaping the socio-cultural, economic and political reality of Central Lika at the beginning of the $21^{\text {st }}$ century. It facilitates a better understanding of the issues this area confronts, and delineates some of the possible solutions.

Once again, it is noteworthy that the articulation of the sustainable development concept is a complex process involving expertise-based knowledge, skills, planning, coordination and cooperation. The theoretical concepts used in this paper are flexible enough to enable collaboration between experts from different fields. It creates possibilities for planning the future with the objective of integral sustainability. It is important to stress that integral sustainability does not discard contemporary achievements and modernization processes, but rather points out the possibility of their use in the most suitable way to ensure survival. As part of the European Union, Croatia has an opportunity to create preserved and simultaneously developed rural areas all of Lika and Lika-Senj County possess specific resources to achieve that objective.

\section{References:}

1. Baker, W. (2003). Socijalnim kapitalom do uspjeha: kako crpsti skrivene resurse iz svojih osobnih $i$ poslovnih mreža. Zagreb: Zagrebačka škola ekonomije i menadžmenta.

2. Banfield, E. C. (1958). The Moral Basis of Backward Society. Illinois: The Free Press Glencoe. (http://coromandal.files.wordpress.com/2011/02/edward-c-banfield-the-moral-basis-of-a-backward-society.pdf).

3. Becker, G. (1964). Exploring Human Capital: Putting Human Back into Strategic Human Resource Management, in: Wright, P. M. and McMahan, G. C. (2011). Human Resource Management Journal, 21 (2): 93-104. (http://lifecoachlisaosborn.com/wpcontent/uploads/2012/05/Exploring.Human .Capital..pdf).

4. Cifrić, I. (2012). Leksikon socijalne ekologije: kritičko promišljanje. Zagreb: Školska knjiga. 
5. Cifrić, I. (2003). Ruralni razvoj i modernizacija: prilozi istraživanju ruralnog identitet. Zagreb: Biblioteka znanost i društvo.

6. Denzin, N. K. and Lincoln, Y. S. (2011). The Discipline and Practice of Qualitative Research: An Introduction, in: Denzin, N. K. and Lincoln, Y. S. (eds.). The Sage Handbook of Qualitative Research, $4^{\text {th }}$ ed. pp. 1-21. (http://www. uk.sagepub.com/upm-data/40425 Chapter1.pdf).

7. Emirbayer, M. and Mische, A. (1998). What is Agency?. American Journal of Sociology, 103 (4): 962-1023. (http://www.ssc.wisc.edu/čemirbaye/Mustafa Emirbayer/ARTICLES files/what\%20is\%20agency.pdf).

8. Geiger, M. (2009). S onu stranu monokulture: tradicijska znanja o okolišu $i$ mreža života. Zagreb: Izdanja antibarbarus.

9. Giddens, A. (2007). Sociologija. Zagreb: Nakladni zavod Globus.

10. Ignjatović, S. and Tomanović, S. (2011). Socijalni kapital i prostor. Sociologija $i$ prostor, 49/191 (3): 296-286. (http://hrcak.srce.hr/index.php?show=clanak\&id clanak jezik=118710).

11. Johansson, S.; Leonard, R. and Noonan, K. (2012). Caring and The Generation of Social Capital: Two Models for a Positive Relationship. International Journal of Social Welfare, 21: 44-52. (http://onlinelibrary.wiley.com/doi/10.1111/j.14682397.2010.00759.x/pdf).

12. Kalanj, R. (2007). Dimenzije modernizacije i mjesto identiteta. Socijalna ekologija, 16 (2-3): 113-156.

13. Lay, V. (2007). Održivi razvoj i vođenje. Društvena istraživanja, 16 (6): 10311055. (http://hrcak.srce.hr/index.php?show=clanak\&id clanak jezik=30085).

14. Leburić, A.; Afrić, V. i Šuljug-Vučica, Z. (2009). Ljudski kapital kao razvojni faktor: rezultati sociološkog istraživanja u Hrvatskoj. Split: Redak.

15. Milas, G. (2005). Istraživačke metode u psibologiji $i$ drugim društvenim znanostima. Zagreb: Naklada Slap.

16. Newton, K. (1999). Social Capital and Democracy in Modern Europe, in: van Deth, J. W.; Maraffi, M.; Newton, K.; Whiteley, P. F. (eds.). Social Capital and European Democracy. London: Routledge. pp. 3-24. (http://www.google.hr/bo oks?hl=hr\&lr=\&id=ZR2EAgAAQBAJ\&oi=fnd\&pg=PP1\&dq=Newton, + K. $+(2008) .+$ $\underline{\text { Social }+ \text { capital+and }+ \text { democracy }+ \text { in }+ \text { modern }+ \text { Europe. } \& o t s=x F y b N L d Y b 4 \& s i g=f a}$ wn5SYwYUPvYy8yvheMsxQXhAo\&redir esc $=\mathrm{y} \# \mathrm{v}=$ onepage\&q\&f=false).

17. Our Common Future (1987). Chapter 2: Towards Sustainable Development. Report of the World Commission on Environment and Development. (http://www. un-documents.net/our-common-future.pdf).

18. Pejnović, D. (2009). Geografske osnove identiteta Like, in: Holjevac, Ž. (ed.). Identitet Like - korijeni i razvitak (Knjiga I). Zagreb: IDZ Ivo Pilar. (http://www. pilar.hr/images/stories/dokumenti/lika/lika_1_mail_r_045.pdf).

19. Putnam, R. D. (1995). Bowling Alone: America's Declining Social Capital. Journal of Democracy, 6 (1): 65-78. (http://xroads.virginia.edu/čHYPER/DETOC/ assoc/bowling.html\#authbio).

20. Putnam, R.D. (1993). Making Democracy Work: Civic Traditions in Modern Italy, in: Boix, C. and Posner, D. N. (1996). Making Social Capital Work: A Review of Robert Putnam's Making Democracy Work: Civic Traditions in Modern Italy. The Weatherhead Centre for International Affairs. Harvard University Paper No. 96-4. (http://dev.wcfia.harvard.edu/sites/default/files/96-04.pdf). 
21. Rogić, I. (2000). Tehnika i samostalnost: okvir za sliku treće hrvatske modernizacije. Zagreb: Hrvatska sveučilišna naklada.

22. Schmidt, C. (2004). The Analysis of Semi-structured Interviews, in: Flick, U.; von Kardorf, E. and Steinke, I. (eds,). A Companion to Qualitative Research. Sage Publication. pp 253-258. (http://sdhprc.ir/download/A Companion to qualitative research.pdf $\#$ page $=268)$.

23. Šalaj, B. (2007). Socijalni kapital: Hrvatska u komparativnoj perspektivi. Zagreb: Fakultet političkih znanosti.

24. Štulhofer, A. (2004). Percepcija korupcije i erozija društvenog kapitala u Hrvatskoj 1995 - 2003. Politička misao, 41 (3):156-169. (http://hrcak.srce.hr/index. php?show=clanak\&id clanak jezik=35692).

25. Tomanović, S. (2006). Primjenjivost Burdjeovog koncepta socijalnog kapitala na proučavanje porodica u Srbiji, in: Nemanjić, M. i Spasić, I. (ur.). Nasljeđe Pjera Burdjea. Beograd: Biblioteka Disput. (file://C:/Documents\%20and\%20Settings/ Korisnik/My\%20Documents/Downloads/Burdije.pdf).

26. Zeman, Z. i Geiger Zeman, M. (2013). Okolišne dimenzije lokalne kulture: kako se u Gospiću promiče održivost?, u: Holjevac, Ž. (ur.). Gospić - Grad, ljudi, identitet. Zagreb - Gospić: IDZ Ivo Pilar.

27. Županov, J. (2002). Od komunističkog pakla do divljeg kapitalizma. Zagreb: Hrvatska sveučilišna naklada.

\section{Used Official Civil Service Web Pages:}

URL. 1. Državni zavod za statistiku (Croatian Bureau of Statistics). (http://www.dzs. hr/s.

URL. 2. ARKOD - sustav evidencije zemljišnih parcela u RH (Croatian National System for Plot Register). (http://www.arkod.hr/). 


\section{Anita Bušljeta Tonković}

Institut društvenih znanosti Ivo Pilar, Područni centar Gospić, Hrvatska

e-mail:anita.busljeta.tonkovic@pilar.hr

\section{Sociološki aspekti mogućnosti održivog razvoja Središnje Like kroz prizmu ljudskog $i$ socijalnog kapitala}

\section{Sažetak}

Ovaj rad prikazuje sociološko viđenje mogućnosti održivog razvoja ličke subregije Središnje Like kroz prizmu ljudskog i socijalnog kapitala. Modernizacijski procesi koji su više mimoilazili negoli mijenjali cjelokupno područje Like za sobom su ostavili očuvan prirodni okoliš i bogate prirodne resurse. Takvo stanje prirodnog okoliša zadovoljava osnovni preduvjet za artikulaciju koncepta održivog razvoja. Rad se temelji na ukrštavanju koncepta održivog ra $\neg$ zvoja s konceptima socijalnog i ljudskog kapitala. Usmjeren je prema socijalno-ekološkoj paradigmi. Za potrebe studije provedeno je kvalitativno empirijsko istraživanje - polustrukturirani intervju u dvije faze, tijekom 2012. i 2013. godine. Subjekti istraživanja bili su odabrani lokalni razvojni socijalni akteri Središnje Like. Rezultati istraživanja omogućili su uvid u postojeće stanje. Također su pomogli pri sociološkoj konceptualizaciji mogućnosti odr-živog razvoja Središnje Like. Rezultati sugeriraju kako se održivost može postići temeljem sljedećih mogućnosti: mjera za demografski oporavak, jačanja civilnog društva, edukacije lokalnog stanovništva, poljoprivrede (integrirane, a potom ekološke), održivog korištenja obnovljivih izvora energije te turizma u sinergiji s poljoprivredom, tradicijom i ekologijom.

Ključne riječi: Središnja Lika, održi razvoj, ljudski kapital, socijalni kapital. 